\title{
Late Givetian Taghanic bioevents in New York State: New discoveries and questions
}

\author{
GORDON C. BAIRD \& CARLTON E. BRETT
}

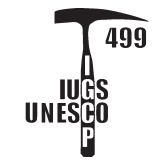

\begin{abstract}
Recent study of late Middle Givetian deposits (upper Moscow Formation, Tully Formation, and lowermost Genesee Group) in east-central New York State, has revealed new, more detailed information concerning the nature and timing of both the "Taghanic transgression" and the Taghanic bioevents in the type region of west-central New York State. The present research focuses on foreland basin detrital facies, peripheral to the classic Tully Limestone succession in western New York; we have documented more complete and complex faunal-facies successions essential for comparison to other regions. These new sections show that it is possible to extend bed-by-bed correlations of typical Tully marker units away from the carbonate platform into both basinal and nearshore detrital deposits, where sections are more complete. The resulting high-resolution stratigraphic framework allows better assessment of the nature and timing of bioevents now recognized in the Taghanic interval in the New York and Pennsylvania region. This paper reviews Taghanic biofacies and focuses on reinterpretation of lower Tully deposits as outer shelf-to-basin facies rather than inner shelf or "lagoonal" facies as previously suggested. The potential relationship of the Tully Fauna to the post-Taghanic Ithaca Fauna is discussed briefly. We also discuss these findings in the context of recent biostratigraphic and geophysical work by others within the Taghanic time-slice, particularly, in Europe and Morocco. $\bullet$ Key words: Givetian, bioevents, incursion, Taghanic Stage, onlap, Catskill Delta.
\end{abstract}

BAIRD, G.C. \& BRETT, C.E. 2008. Late Givetian Taghanic bioevents in New York State: New discoveries and questions. Bulletin of Geosciences 83(4), 357-370 (6 figures). Czech Geological Survey, Prague. ISSN 1214-1119. Manuscript received September 19, 2006; accepted in revised form August 20, 2007; issued December 31, 2008.

Gordon C. Baird, Department of Geosciences, S.U.N.Y. Fredonia, Fredonia, NY, 14063, U.S.A; Gordon.Baird@fredonia.edu • Carlton E. Brett, Department of Geology, University of Cincinnati, 500 Geology/Physics Bldg., Cincinnati, OH 45221-0013, U.S.A; Carlton.Brett@uc.edu

The late Middle Devonian (upper Polygnathus ansatus-Ozarkodina semialternans Zone) Tully Formation in New York State is an anomalous carbonate unit within thick, terrigenous deposits of the Catskill Delta complex, a large, westward prograding clastic wedge within a Devonian foreland basin. It is essentially a clean, typically micritic limestone that forms ledges, quarry walls, and waterfalls from its westward erosional terminus near Canandaigua Lake in western New York eastward to central New York (Fig. 1). The Tully was noted for the occurrence of the brachiopod Hypothyridina "cuboides" (now Tullypothyridina venustula Sartenaer, 2003) and other distinctive taxa as far back as the mid-nineteenth century. Johnson (1970) coined the term "Taghanic onlap event" for widespread cratonward onlap of marine units beginning in the Po. ansatus Zone at the onset of Tully Formation deposition. As shown by Heckel (1973) a significant unconformity occurs within the Tully Formation which locally truncates or completely removes the lower Tully units. Baird \& Brett (2003) documented a second, higher unconformity that regionally divides Heckel's "upper Tully" into two units. During deposition of the upper Tully Formation, a major transgression accompanied upward change from clean carbonate to increasingly muddy limestones, and culminated in the overspread of anoxia and resulting black mud deposition within the foreland basin; this deepening partly reflects eustatic highstand conditions (Johnson et al. 1985), but it also was greatly enhanced by flexural loading of the craton by thrust slices during a collisional pulse (Third Tectophase) of the ongoing Acadian Orogeny (Ettensohn 1998). Additionally, Tully strata record major faunal fluctuations associated with the regional demise and/or geographic restriction of the long lasting, diverse, and endemic Hamilton Fauna (Brett \& Baird 1995, 2003, Sessa et al. 2002, Baird et al. 2003); this pattern of faunal overturn and global extinctions, known as the "Taghanic Event"(Johnson 1970, House 1981), is increasingly recognized as actually representing two or more temporally closely-spaced global bioevents which may have been as severe, or more so, than the widely-known Frasnian-Famennian extinction (Aboussalam \& Becker 2001, House 2002, Aboussalam 2003). 


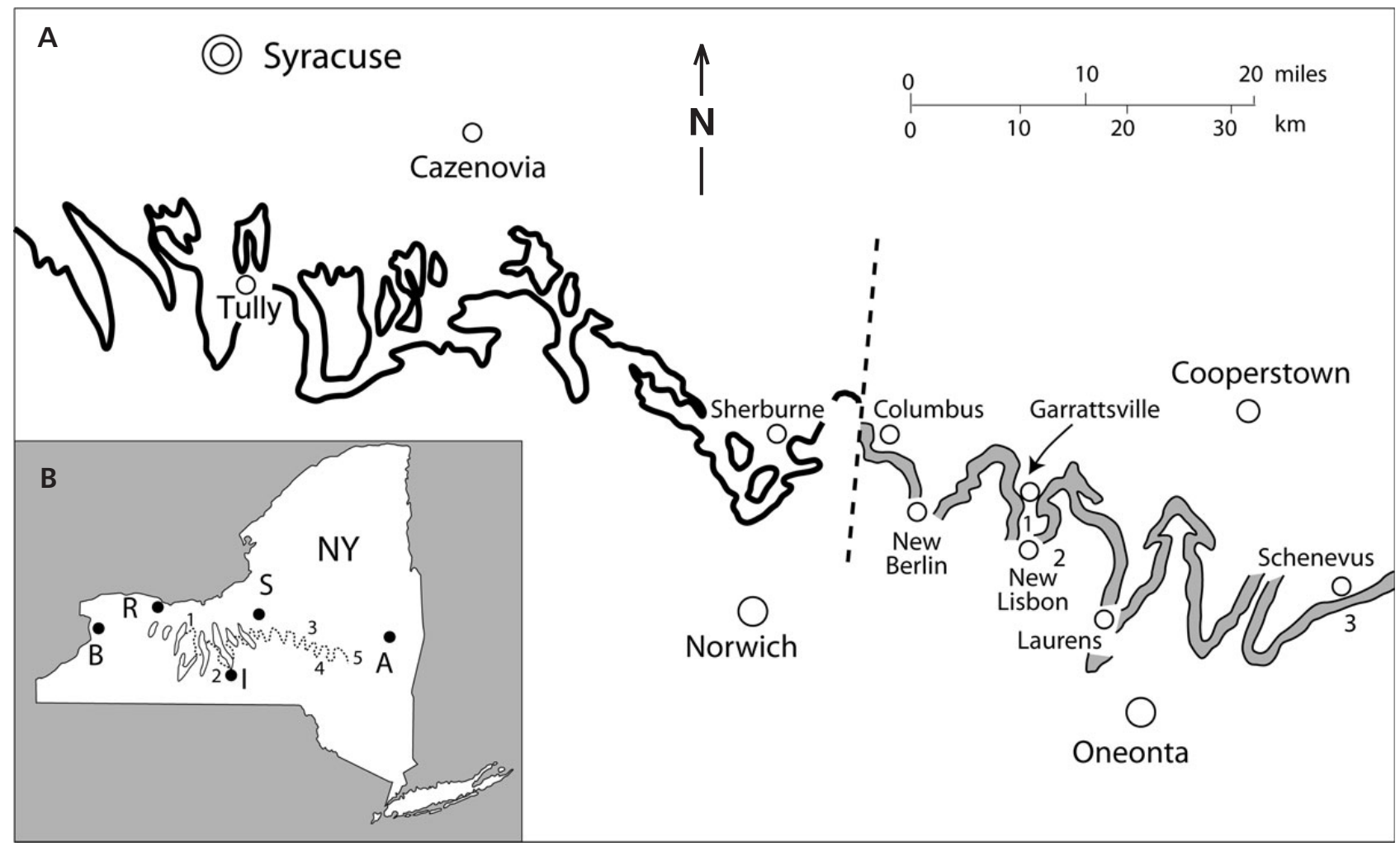

Figure 1. Study area. - A - east-west-trending outcrop belt of Tully Formation (black line) and Tully-equivalent clastic correlative succession (grey belt) relative to inferred fault near Columbus, NY. Numbered outcrops discussed in text include: 1 - newly discovered long section near Garrattsville, 2 - type section of New Lisbon Member east of New Lisbon, 3 - long roadcut and creek section southeast of Schenevus. B - Tully sections in New York State. Cities are lettered: B - Buffalo, R - Rochester, S - Syracuse, I - Ithaca, A - Albany. Sections are numbered: 1 - westernmost Tully sections near Canandaigua Lake, 2 - type Taghanic section at Taughannock Falls, 3 - Garrattsville section, 4 - New Lisbon type section, 5 - Schenevus sections.

Because of the unusual lithologies and major patterns of faunal change associated with the Tully Formation, this unit presents an opportunity to examine a variety of coincident paleontological, sedimentological, eustatic and structural changes associated with the global Taghanic Event in its type area. The present authors, commencing work on the Tully ten years ago, have focused on extending correlations eastward within the Taghanic interval and defining more precisely the faunal succession and biofacies units in that interval. Given the structural simplicity of our field area, we have applied a "brute force" approach in that all available sections are measured and included in correlations; as such, the number of sections examined from Sherburne eastward has been increased from approximately ten, as observed by earlier workers, to fifty eight. Detailed unit-section descriptions and correlations are published in guidebook proceedings (Baird et al. 2003). Recent revisions in stratigraphic correlations, particularly within the Tully Formation Clastic Correlative Succession ("TFCCS") in eastern New York, which includes detrital facies correlative with Tully carbonates in western New York, will be reviewed here. In addition, the faunal (biofacies) succession from the topmost Moscow Forma- tion through the Taghanic interval has also been refined, particularly, within the TFCCS. This paper will focus on the timing and character of Taghanic bioevents, the discovery of key new sections in the TFCCS and the reinterpretation of lower Tully facies, the apparent selective impact of the Tully Fauna incursion on dysoxic biofacies, and possible relationships of the Tully Fauna to the post-Taghanic Ithaca Fauna.

\section{Previous work}

Initial studies of the Tully Formation were undertaken by Grabau (1917) and Trainer (1932). These efforts were followed by more detailed work on this interval in New York State by Cooper \& Williams (1935) and by Willard (1937) in Pennsylvania. Cooper \& Williams (1935) recognized that clean micritic carbonate comprising the Tully Formation in western New York passed eastward into thin, partly chamositic, and largely detrital deposits near the town of Sherburne in east-central New York before expanding greatly into a clastic wedge to the east of there. The most detailed and important Tully study is that of Phillip Heckel who 
undertook a bed-scale correlation approach for Tully sections between Canandaigua lake and the Sherburne area in the 1960s and 1970s (Heckel 1966, 1973). Numerous key beds and contacts mapped by Heckel revealed that lower Tully beds, visible in west-central New York, were erosionally overstepped to the east and west of there by a discontinuity within the Tully, such that, at Sherburne, the thin Tully, originally described by Cooper \& Williams (1935), was a condensed expression of only the medial and upper Tully succession (Heckel 1973). A variably chamositic, thin layer, designated the Smyrna Bed by Heckel (1973) was found to be closely associated with this erosional overstep. The thick, detrital sediment wedge east of Sherburne was interpreted to represent very shallow facies that accumulated on the eastern, down dropped side of a fault; syndepositional fault activity created a "clastic trap" that accounted for anomalous facies and thickness changes over a narrow interval (Heckel 1973). Johnson \& Friedman (1969) presented new sedimentological data from Tullyequivalent nearshore deposits (Gilboa Sandstone and associated units) in eastern New York and identified a variety of coastal facies. However, neither these authors, nor Heckel, attempted detailed correlations in the region east of Sherburne.

Baird \& Brett (2003) and Baird et al. (2003) extended correlations into TFCCS deposits in the New BerlinOneonta area of east-central New York (Figs 1-3). Moreover, upon reassessing the facies of the Tully Formation in the context of sequence stratigraphy, they redefined the base of Johnson's (1970) Taghanic onlap event upward from the base of the Tully, as originally defined, to a lowstand event associated with deposition of the shallow neritic Bellona/West Brook beds of the upper Tully (see facies discussion below). As redefined, transgressive deepening, commenced upward from an erosion surface flooring the Bellona Bed through the Moravia and succeeding Fillmore Glen beds of the highest Tully into the Geneseo black shale (Baird \& Brett 2003, Baird et al. 2003).

Baird \& Brett $(1986,1991)$ examined the relationship of the Tully Limestone in western New York to the overlying Geneseo Formation, a black, fissile shale recording widespread, highstand-related anoxia within the Devonian foreland basin. Through this work, they recognized that a bed of detrital pyrite and bone debris (Leicester Member), capping Tully carbonates and older Windom strata west of the Tully erosional terminus (Fig. 2), was the result of combined submarine erosion and carbonate dissolution in a primarily dysoxic to anoxic basinal regime. Moreover, the Leicester is demonstrably a post-Tully deposit, which is time-correlative to the Geneseo Formation (Huddle 1981, Baird \& Brett 1986); it is associated, in part, with corrosional westward truncation of Tully carbonate near Canandaigua Lake and sub- sequent diachronous, westward onlap of Geneseo black shale deposits along the sub-Geneseo Taghanic Unconformity (Johnson 1970, Johnson et al. 1985; Fig. 2). This onlap event is partly the expression of westward flexural basin subsidence associated with the collisional "Third Tectophase" of the Acadian Orogeny (Ettensohn 1998) and partly a result of a global eustatic highstand event (Johnson et al. 1985).

\section{Taghanic chronostratigraphy and global context}

The study interval, including strata from the upper part of the pre-Tully Moscow Formation to the base of the (postTaghanic) Geneseo Formation, chronostratigraphically includes part of the Middle Givetian substage up to the base of the Upper Givetian substage as recently defined (see Becker 2005, 2007, Figs 2, 3). Biostratigraphic work on the Tully interval, based on conodonts was undertaken by Ziegler et al. (1976) and Huddle (1981). Work on the ammonoids was undertaken by House $(1962,1978)$ and summarized by House (1981). Strata of the highest Hamilton Group succession below the Tully contain conodonts corresponding to the upper part of the Polygnathus ansatus Zone (= upper part of Middle varcus Zone of earlier terminology). The lower and medial Tully corresponds to the uppermost part of the Po. ansatus (= Middle varcus) Zone. From the DeRuyter Bed at the base of the Tully into the lower part of the Moravia Bed, a diverse suite of ansatus Zone elements was found, including Polygnathus alveoliposticus in the Carpenter Falls Bed (Ziegler et al. 1976, Klapper 1981). Strata of the uppermost Tully (lower part of Moravia Bed up through overlying Fillmore Glen Bed to the top of the formation) are characterized, first, by the appearance of Ozarkodina semialternans, with the zonally important ammonoid Pharciceras amplexum, in the lower part of the Moravia Bed followed shortly by Schmidtognathus latifossatus (House 1962, 1978; Ziegler et al. 1976). These fossils mark the base of the $O z$. semialternans Zone (formerly Upper varcus Zone) the topmost zone of the Middle Givetian substage, as currently defined Becker (2005, 2007). Succeeding black shale strata of the oldest portions of the post-Tully Geneseo Formation correspond chronostratigraphically to the lower part of the Upper Givetian substage (sensu Becker 2005, 2007); the oldest Geneseo strata yield the conodonts Polygnathus ectypus and Po. ordinatus, both referable to the upper hermannicristatus Subzone (Huddle 1981, Klapper 1981, Kirchgasser 2000).

In Europe, the Tully Formation correlates chronostratigraphically to a disparate spectrum of sections in the Variscan fold and thrust belt, including: the basal (transgressive) part of the Fromelennes Formation in the 


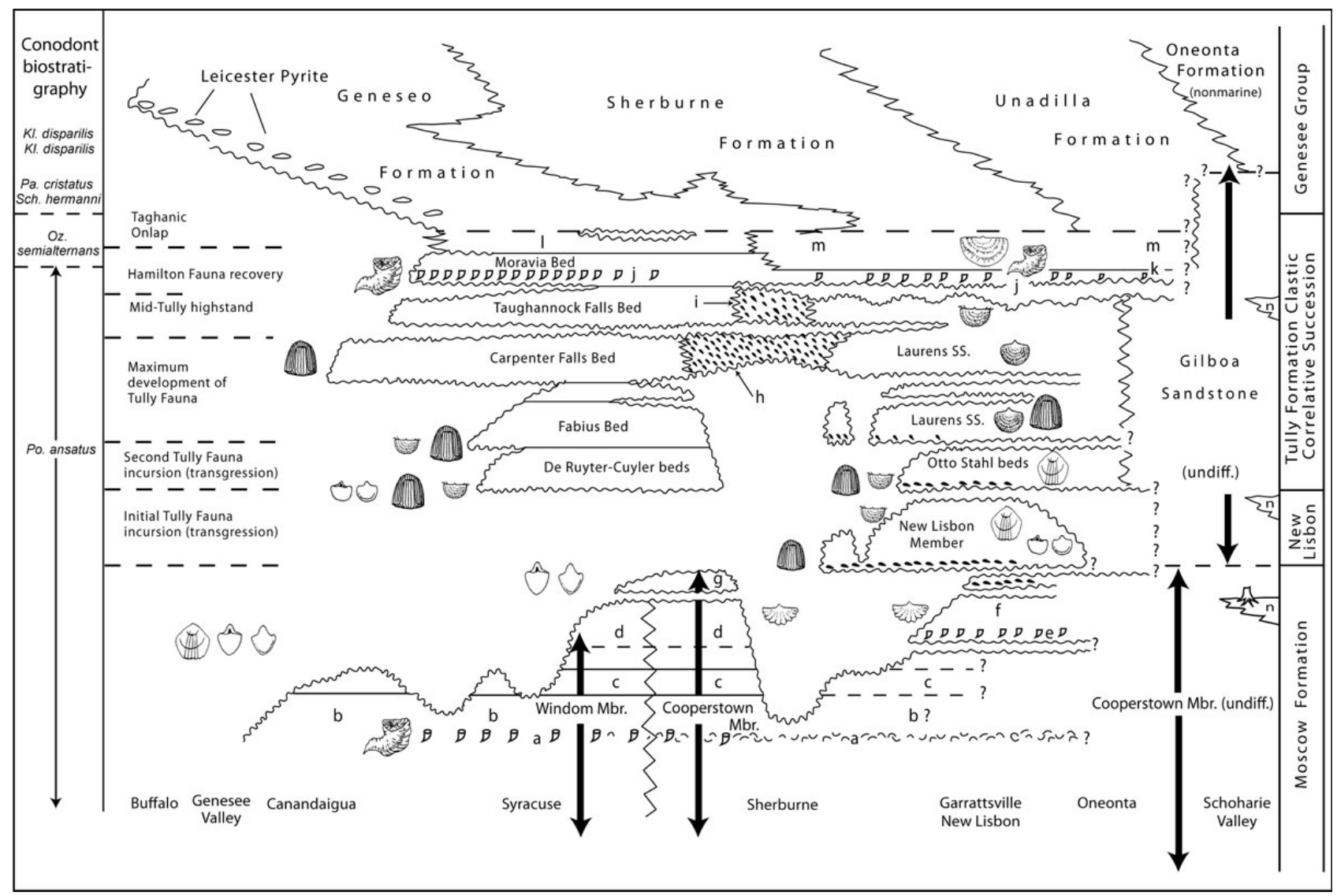

Figure 2. Revised time-stratigraphic chart for the Tully Formation and associated units in New York State based on work of Baird \& Brett (1986, 2003), and Baird et al. (2003, 2005). Note multiple unconformities below-, and within, Tully Formation, near closure of discontinuities at the Garrattsville - New Lisbon meridian, and westward onlap of Geneseo black shale facies (transgressive, post-Tully, Taghanic onlap pattern). Lettered units include: a - Lansing shell/coral Bed, b - Spezzano submember, c - Gage Gully submember, d - Sheds submember, e - coral bed in eastern equivalent of Sheds submember, $\mathrm{f}$ - upper shaly part of interval equivalent to the Sheds submember, $\mathrm{g}$ - Highland Forest submember, $\mathrm{h}$ - Smyrna Bed (chamosite), i - "Taughannock Falls chamosite Bed" of Heckel (1973), j - West Brook Bed, k - quartz pebble bed equivalent to West Brook Bed, 1 - Fillmore Glen Bed, $\mathrm{m}$ - shaly strata equivalent to Moravia Bed-Fillmore Glen Bed-succession; $\mathrm{n}$ - nonmarine (red bed) tongues extending westward into nearshore marine deposits. Note symbol for Gilboa tree stump above red bed tongue in uppermost Cooperstown Member succession.

Belgian carbonate platform of the Ardennes region (Johnson et al. 1985, Bultynck et al. 2000), the Discoides Limestone of the Sauerland region of the Rheinisches Schiefergebirge (Aboussalam 2003), and the Prague Basin and Moravian Karst area successions of the Czech Republic (Hladil 1994, Chlupáč et al. 2000, Ellwood et al. 2006, Hladil et al. 2006). This greater region was characterized by syn-Taghanic tectonics resulting in a complex paleotopographic mosaic with reef build-ups on structural highs and concurrent terrigenous and allodapic carbonate accumulation with associated pelagic faunas in synjacent basins. The most significant discoveries in the Taghanic time slice are currently being made in the Moroccan Tafilalt area of the northern Anti Atlas Mountains (see Bultynck \& Walliser 2000, Aboussalam 2003, Becker 2007). In this region, beds can be traced over long distances and the overprint of extrabasinal eustatic and bioevent signatures is clearly recognizable, particularly, through the use of magnetosusceptibility stratigraphic techniques (see Ellwood et al. 1997, 2000; Crick et al. 2002). Future comparison of the well-ordered Moroccan and New York sections is an ongoing goal of the present authors.

\section{Revised TFCCS stratigraphic and biofacies succession}

A goal of the present work is to identify the most complete chronostratigraphic section bridging the transition from the underlying Windom and Cooperstown Members, bearing typical Hamilton Fauna taxa, to strata yielding Tully Fauna elements (Figs 2-5). At the type Taghanic section near Ithaca, New York, medial Tully strata (Carpenter Falls Bed) rest disconformably on a truncated upper Windom section. Further east, beds comprising the lower Tully succession beneath the Carpenter Falls Limestone, as well as units of 


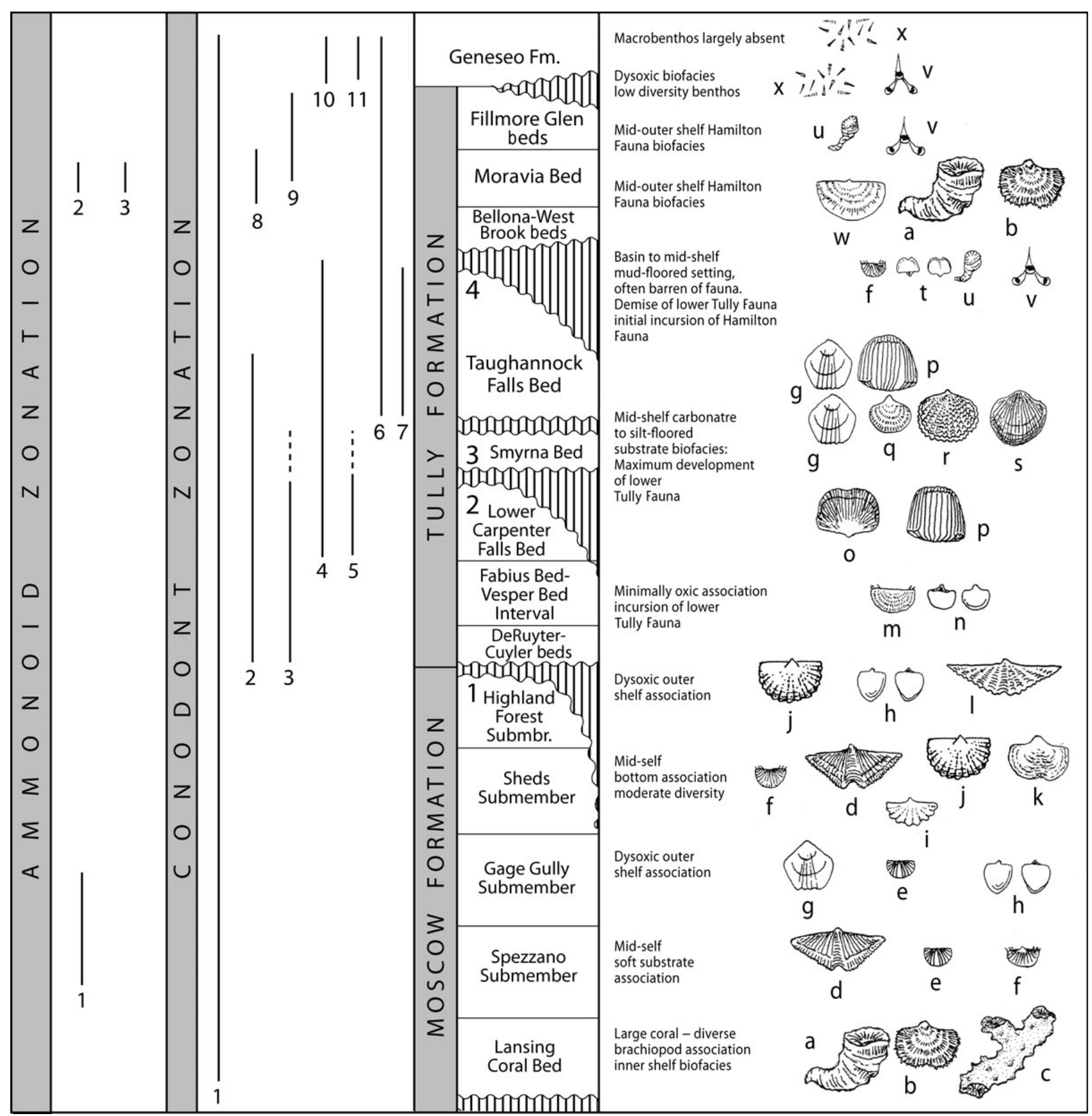

Figure 3. Generalized faunal succession in the upper Windom Member and Tully Formation succession in central New York (Syracuse meridian) correlated to conodont and ammonoid zonation. This schematic shows the influx of the Tully Fauna at the base of the Tully Formation (DeRuyter Bed-level), reestablishment of the diverse Hamilton Fauna association in the upper Tully Formation (Bellona/West Brook Bed-level), and the decline of faunal diversity in the highest Tully owing to the onset of transgression-related dysoxia in the Moravia Bed-Fillmore Glen Bed-interval. Key lowstand unconformities include: the base-Tully (1), base-middle Tully (2), and base-West Brook (4) sequence disconformities. Maximum flooding surface contacts include: the top-Smyrna Bed unconformity (3) and the top-Fillmore Glen corrosional discontinuity (5). Diagnostic and/or common taxa include: a - Heliophyllum halli, b-Spinatrypa spinosa, c - large bryozoans, d - Mediospirifer audaculus, e - Allanella tullius, $\mathrm{f}$ - Devonochonetes scitulus, g-Camarotoechia ("Leiorhynchus") mesocostale (in the Tully, this taxon is restricted to the TFCCS in eastern New York and Pennsylvania), $\mathrm{h}-$ Emanuella praeumbona, $\mathrm{i}-$ Pustulatia (Vitulina) pustulosa, $\mathrm{j}$ - Tropidoleptus carinatus, $\mathrm{k}$ - Athyris spiriferoides, 1 - Mucrospirifer spiriferoides, $\mathrm{m}-$ Rhyssochonetes aurora, $\mathrm{n}-$ Emanuella subumbona, o-Schizophoria tulliensis, $\mathrm{p}$ - Tullypothyridina venustula, $\mathrm{q}$ - Echinocoelia ambocoeloides, $\mathrm{r}-$ Spinatrypa $\mathrm{sp} ., \mathrm{s}-$ Pseudoatrypa devoniana, $\mathrm{t}$-Ambocoelia umbonata, $\mathrm{u}$ - small rugosan, $\mathrm{v}$ - auloporids, $\mathrm{w}$ - Leptaena rhomboidalis, $\mathrm{x}$ - styliolines. Key conodonts include: 1 - Icriodus latericrescens latericrescens, 2 - Polygnathus timorensis, 3 - Polygnathus ansatus, 4 - Polygnathus beckmanni, 5 - Polygnathus alveoposticus, 6 - Icriodus difficilis, 7 - Polygnathus varcus, 8 - Ozarkodina semialternans, 9 - Polygnathus latifossatus, 10 - Polygnathus cristatus, 11 - Polygnathus disparalvea. Key goniatites include: 1 - Tornoceras (T.) cf. uniangulare, 2 - Pharciceras amplexum, 3-Tornoceras (T.) cf. arcuatum (modified from Baird \& Brett 2003). 
the uppermost Windom, appear below the Tully in southeastern Onondaga County (Heckel 1973, Baird \& Brett 2003, Baird et al. 2003; Figs 1, 2). At Sherburne, both lower Tully and topmost Windom units are again missing along a disconformity flooring the Smyrna Bed, a condensed, medial Tully chamosite-rich unit roughly corresponding to the Carpenter Falls Limestone in western New York (Fig. 2). East of an apparent fault zone, $8 \mathrm{~km}$ east of Sherburne, the Tully interval thickens abruptly eastward into distinctly basinal siliciclastic facies in the $\mathrm{New}$ Berlin-New Lisbon area; this depocenter termed the "Columbus Sag" is marked by the reappearance of the lower Tully succession as well as strata (New Lisbon Member) intermediate to both the underlying Moscow Formation and overlying beds of the TFCCS (Figs 2, 4, 5).

A chamosite-rich discontinuity layer, separating basal New Lisbon strata from underlying Moscow beds, is now recognized in this region. This observation, plus the recent discovery of Tullypothyridina and Rhyssochonetes in association with abundant Camarotoechia mesocostale within the lower few meters of the New Lisbon at sections $1.1 \mathrm{~km}$ southeast of Garrattsville, NY in the Butternut Valley (Figs 4, 5), show that the New Lisbon is now understood to display Tully as well as Hamilton biotic affinities (Baird et al. 2003). At Garrattsville, topmost Cooperstown (Windom) Member strata are found to be nearly in continuity with the New Lisbon, providing a nearly complete Hamilton-Tully transition (Figs 2, 4, 5). At and near the New Lisbon type section, the "New Lisbon Member", as previously defined (Cooper \& Williams 1935), reaches its greatest thickness, and it displays an internal discontinuity. As noted by Heckel (1973), it is probable that the upper New Lisbon division corresponds roughly to the lowest Tully divisions (DeRuyter and Cuyler beds) further west. However, based on a mixture of Hamilton and Tully elements (Tullypothyridina, Rhyssochonetes, Tropidoleptus, Allanella) found in the lower New Lisbon division at Garrattsville, we argue that this unit is older than any Tully division recognized further west in New York and that it appears to record the initial incursion of the Tully Fauna (Figs 2-5).

The definitional status of the "New Lisbon Member", both as to what beds it will eventually include as a unit, and whether one component division, or both, will be eventually included in the Tully, is not fully resolved. At and near its type section, along Otto Stahl Road, $1.6 \mathrm{~km}$ northeast of New Lisbon, NY in the Butternut Valley, the "New Lisbon Member" (sensu Cooper \& Williams 1935) reaches its greatest thickness, and it displays an internal discontinuity. We suggest, as did Heckel (1973) that the "upper New Lisbon" division corresponds roughly to the lowest Tully divisions (DeRuyter and Cuyler beds) further west. Hence, we provisionally restrict the term New Lisbon, herein, to the lower part of Cooper \& Williams (1935) original "New
Lisbon Member" interval; this includes strata that are above the Cooperstown Member, commencing with a basal chamositic bed, and below the internal discontinuity contact noted above (Baird et al. 2003; Figs 4, 5). This interval is characterized by thin, flaggy siltstone beds and interbedded shale layers abounding in Camarotoechia mesocostale. Above this discontinuity, the former upper part of Cooper and Williams's (1935) "New Lisbon" interval is now included within the basal part of the TFCCS (see usage in Figs 4, 5). At the New Lisbon outcrop, this 9 meter-thick interval, informally termed the "Otto Stahl Road beds" herein, is characterized by sandstone beds containing numerous Camarotoechia mesocostale.

Developed within the New Berlin-Laurens area, is the "Laurens Member", a loosely defined unit within the TFCCS originally defined by Cooper \& Williams (1935). We believe that this unit is approximately equivalent to the post-Cuyler Bed "lower Tully" succession of Heckel (1973); as such, it corresponds to the Fabius Bed-Carpenter Falls Bed interval of the central New York Tully succession and probably also to some portion of the higher Taughannock Falls Bed interval as well (Figs 2, 3). The Laurens Member includes several key shell beds identified by Baird \& Brett (2003) and Baird et al. (2003) as well as facies characterized by the highest diversity of Tully Fauna taxa (Figs 2, 4, 5). Above this fossil-rich interval is a thick succession of sparsely-fossiliferous beds yielding a few residual Tully Fauna taxa (Rhyssochonetes, Emanuella, "Echinocoelia" - Fig. 2). Because these beds underlie the West Brook Shale, we believe that they correspond to the Taughannock Falls Bed-succession, an interval marking transgressive to highstand deposits (Baird et al. 2003).

The West Brook Shale is a fossiliferous, thin reference stratum well known to Tully workers (Cooper \& Williams 1935, Heckel 1973, Baird \& Brett 2003, Baird et al. 2003); it is the eastern equivalent of the Bellona Bed, a thin coral-rich layer in western New York Tully sections (Figs 2,3) marking a major lowstand event followed by the onset of the Taghanic transgression as redefined by Baird \& Brett (2003). The Bellona and West Brook beds record a spectacular return of the Hamilton Fauna in the form of biotas yielding large rugosans, alveolitid tabulates, fenestrate and cryptostome bryozoans, and diverse brachiopods including: Douvillina, Elita, Spinatrypa, Mediospirifer, Mesoleptostrophia, Nucleospira, Rhipidomella, and Tropidoleptus, as well as trilobites including the phacopids Eldredgeops and Bellacartwrightia cf. calliteles, and the proetid Basidechenella rowi. In eastern New York sections, it rests unconformably on sparsely fossiliferous deposits as it does also in central Pennsylvania; it is the most fossil-rich Tully unit and the most widespread (Fig. 2). We interpret the Bellona-West Brook interval to record a eustatic lowstand and early transgressive event permitting 


\section{Cooperstown Member - into - basal Tully Formation Clastic Correlative Succession: Creek Southeast of Garrattsville, NY}

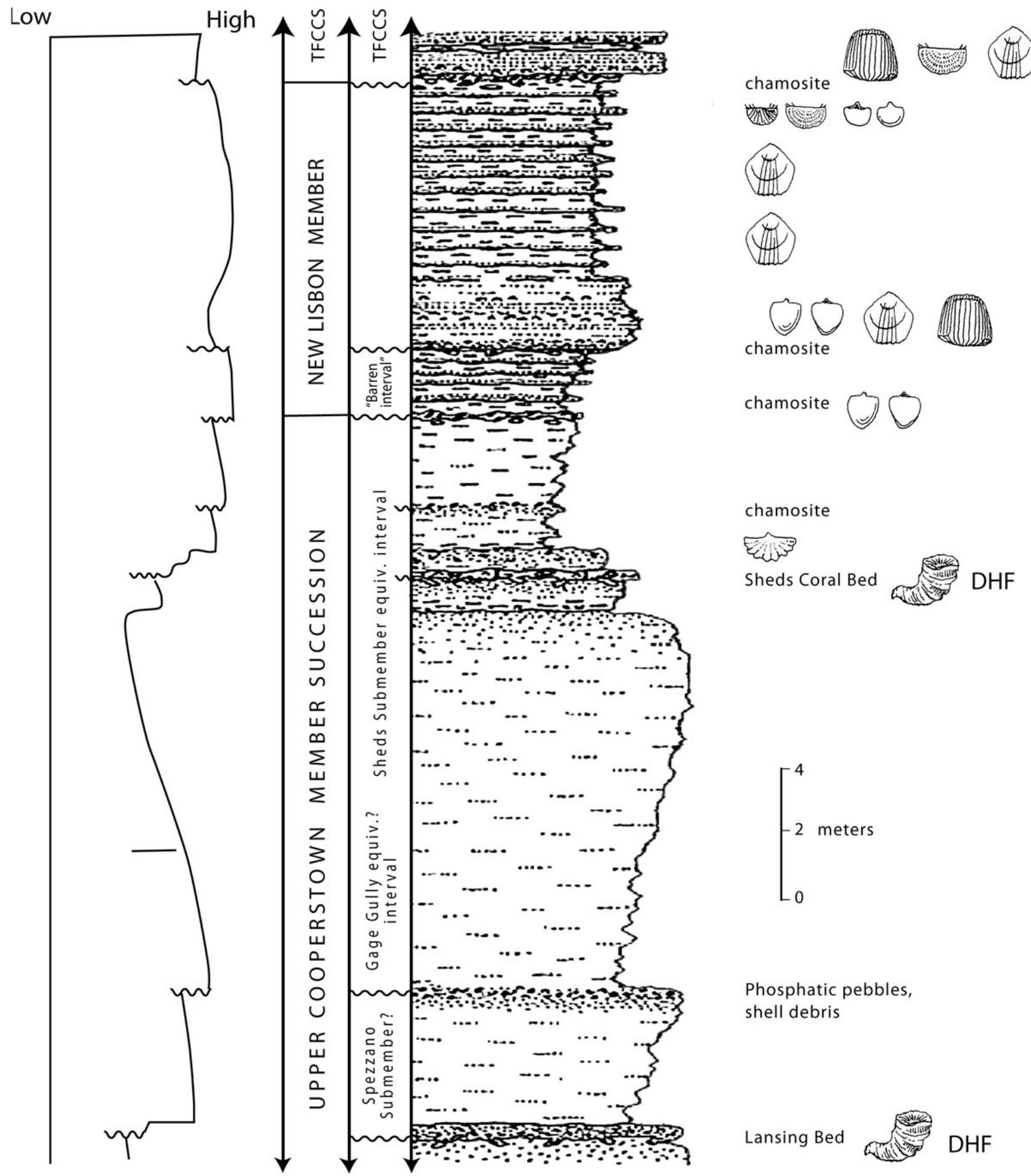

Figure 4. Part of newly discovered long section 1.1 kilometer southeast of Garrattsville, NY showing Cooperstown-into-basal TFCCS interval. This section shows both basal and top contacts of the lower (pre-Tully) division of the New Lisbon Member which is herein labeled "New Lisbon" on column. Because the New Lisbon Member, as originally defined by Cooper \& Williams (1935), is now found to display, respectively, two divisions, the lower one pre-Tully, and the upper one within the basal TFCCS, we provisionally restrict the term New Lisbon Member to the lower division only (see text). Note the occurrence of Tullypothyridina and chamosite in basal New Lisbon beds (above the discontinuity lag beds marking the base of the New Lisbon) and the occurrence of rare Rhyssochonetes near the top of the unit. This locality displays the most complete Moscow Formation-lower Tully succession observed in New York State. Fossils shown are keyed to symbols in Fig. 3. DHF - Diverse Hamilton Fauna. 
a return of diverse mid-shelf, neritic taxa across the foreland basin region (Baird \& Brett 2003, Baird et al. 2003). This interpretation is supported by recent discovery of a coral-brachiopod-bearing quartz pebble bed at the estimated likely level of the West Brook event within the westernmost Gilboa Sandstone at Schenevus, New York (Fig. 6); this bed is a shoreward expression of initial transgressive deepening over an apparent sequence boundary unconformity with associated mid- to inner shelf taxa present (Baird et al. 2005).

Above the Bellona and West Brook beds within the Tully, several Hamilton taxa persist, but decrease markedly in diversity as dysoxic and, finally, near-anoxic conditions overspread the basin during the Taghanic Transgression. Pelmatozoan debris, fistuliporoid bryozoans, and a few Spinatrypa persist into the lowest Moravia Bed interval above the West Brook Bed (Heckel 1973). Higher, within the Moravia Bed, Ambocoelia, rare Athyris, diminutive Eldredgeops, diminutive rugosans, and auloporid corals are characteristic. The overlying Fillmore Glen Member, where developed, records an upward facies passage into the Geneseo black shale; this unit contains styliolines, auloporids, and sparse, small rugosans. The zonally important ammonoid Pharciceras amplexum occurs in the lower part of the Moravia Bed, but has not been found in the West Brook/Bellona beds or in lower Tully divisions (House 1978, 1981). As such, it co-occurs with the modest Hamilton Fauna association seen in the Moravia Bed.

\section{Chronology of bioevents}

The Taghanic Bioevents were preceded by a long (4-5 Ma) interval of relative ecological-evolutionary stability that spanned the Early Givetian and most of the Middle Givetian (Brett \& Baird 1995, see recent redefinition of Givetian substages, Becker 2005, 2007). This interval of biofacies stability was marked by the temporal persistence of most species comprising the long-standing Hamilton Fauna, characteristic of strata below the Tully Formation (Brett \& Baird 1994, 1995; Fig. 3). The Moscow Formation, representing the uppermost Hamilton formational division, contains marine deposits with diverse Hamilton taxa. The medial and upper Moscow succession is represented by the shaly Windom Member in western New York and by coeval near-shore silty/sandy facies of the Cooperstown Member in east-central New York (Fig. 2). In eastern New York, the Cooperstown Member grades laterally into non-marine "red bed" deposits (Fig. 2). One unit (New Lisbon Member) in east-central New York appears to bridge the widespread temporal hiatus between Hamilton and typical Tully deposits (see below).

The conformable succession records two main episodes of major faunal changes, each divisible into two subsidiary bioevents (see Figs 3-5) for a total of four bioevents. The first two bioevents correspond to a two-phase (stepwise) incursion of the Tully Fauna near the base of the Tully, and the second two bioevents respectively record the return of the Hamilton Fauna in the upper Tully West Brook/Bellona beds and the transgression-related appearance of pelagic taxa at a still-higher level.

In the first episode of faunal change, herein termed the Lower Tully Events, several key Old World Realm brachiopod taxa belonging to the Tully Fauna appear in sections with a concommittent outage of key Hamilton forms in the lower and medial Tully interval (Fig. 3). This occurs in two distinct stages. The first is marked by the appearance of two taxa, Tullypothyridina and Rhyssochonetes in the pre-Tully (restricted) New Lisbon Member, while the second involves the appearance of the complete complement of Old World Realm Taghanic brachiopod taxa at the base of the main Tully and TFCCS successions (Figs 2-5).

The third and fourth bioevents, herein defined as the Taghanic Events (sensu stricto), are recorded in the upper Tully succession and are associated with the onset of the Taghanic transgression (Baird \& Brett 2003, Baird et al. 2003). The third bioevent marks the apparent return ("recovery") of the diverse neritic Hamilton Fauna in the Bellona/West Brook beds of the upper Tully, and the fourth bioevent marks the first appearance of pelagic organisms, including zonally important taxa, within the transgressive Moravia Bed-Fillmore Glen Bed interval and the disappearance of many typical Hamilton forms (Fig. 3).

The initial two Taghanic bioevents were actually preceded by two similar transgression-related incursions of Emanuella praeumbona in association with Eumetabolotoechia cf. multicosta (formerly "Leiorhynchus") during deposition of the upper part of the Moscow Formation. These taxa are distinctly restricted to dark shale intervals in the Windom Member (Fig. 3). As noted above, Emanuella subumbona, and Camarotoechia mesocostale make their first appearance in analogous distinctly offshore facies of the New Lisbon Member sensu stricto (Figs 2, 4, 5). Indeed these two taxa are ecological analogues and may be evolutionarily related to the earlier forms E. praeumbona and E. multicosta, respectively. In higher, more oxic, strata of the redefined New Lisbon, Hamilton elements stage a weak comeback in association with rare Rhyssochonetes (Figs 4, 5). This pattern suggests that replacement of Hamilton associations by those dominated by typical Tully elements occurred initially in deeper shelf-basinal, dysoxic facies, while shallower shelf areas retained typical Hamilton biofacies (Sessa et al. 2002, Baird \& Brett 2003). This interpretation based on Waltherian inference is also supported by lateral (downslope) replacement of shallow to deeper shelf biofacies along a single time-parallel transect. 


\section{New Lisbon Member - into - Tully Formation Clastic Correlative Succession: Creek northeast of New Lisbon, NY}

Low High

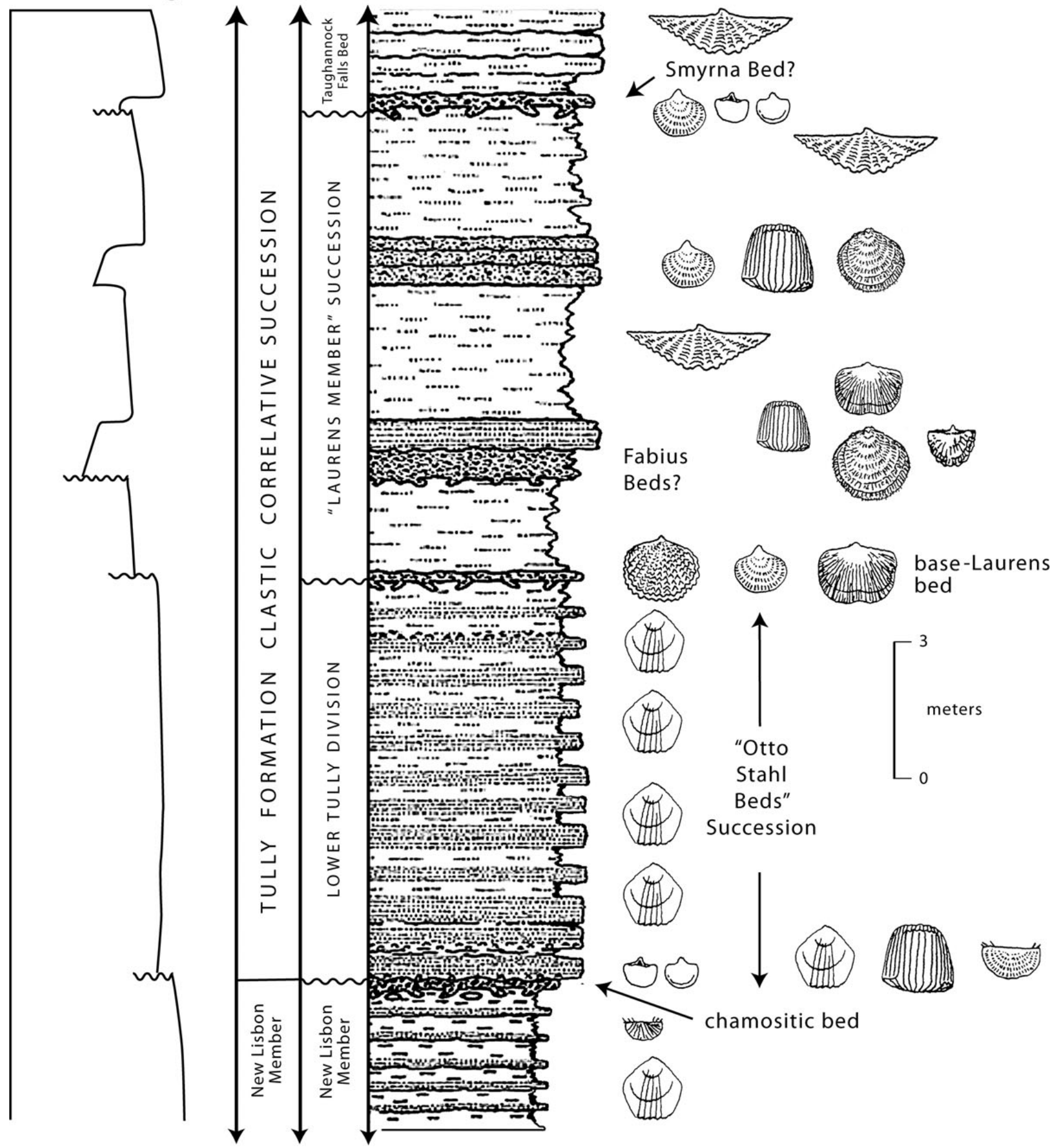

Figure 5. Lower end of section 1.6 kilometers northeast of New Lisbon, NY along Otto Stahl Road [Cooper \& Williams (1935) type New Lisbon Member section] showing top of lower part of the pre-Tully New Lisbon succession (herein labeled "New Lisbon" on column). The former upper part of New Lisbon ("Otto Stahl" Road quarry sandstone beds), above the chamositic discontinuity layer, are now included in the basal interval of the TFCCS below the Laurens Member (see text). Note the occurrence of Tullypothyridina, Rhyssochonetes, and Emanuella in the base-TFCCS discontinuity lag layer and the dominance of Camarotoechia mesocostale in the succeeding 8-meter sandstone interval. Fossils shown are keyed to symbols in Fig. 3. 
A typical mid shelf Hamilton Fauna in the Taughannock Falls Bed grades laterally into a low diversity Tully faunal association within equivalent upper medial Tully deposits in more basinal TFCCS facies in east-central New York and central Pennsylvania.

In the "Otto Stahl Road" division (formerly upper New Lisbon Member), Tully taxa make a more sustained invasion within dysoxic facies and remain dominant within moderate diversity, oxic, outer shelf deposits of the lower Tully and equivalent TFCCS. This pattern further suggests a gradual, stepwise, advance of the eurytopic as well as more normal, oxic-adapted Old World Realm taxa into neritic settings with each succeeding transgression in a series of four such events, commencing with dark shales in the two upper Windom Shale cycles (Baird \& Brett 2003, Baird et al. 2003).

A pattern of stepwise faunal change is in accord with the findings of Aboussalam \& Becker (2001), Aboussalam et al. (2001), Aboussalam (2003) who show that several long-standing pre-Taghanic taxa (Agoniatites, Sobolewia) survived into the lower-medial Tully interval, and others (Sellagoniatites, Maenioceras, Gerastos) persist into upper Tully levels, even overlapping the range of the earliest Pharciceras. Instead of an abrupt mass extinction, the Taghanic interval records a general deterioration of marine environments, apparently starting within dysoxic facies, with concurrent processes of extinction, faunal incursion, and community restructuring (Aboussalam \& Becker 2001). That the diverse Hamilton Fauna is still recognizable in the upper Tully following the incursion and possible exit of the Tully Fauna is a testament to the ecological resilience of this association. It is also consistent with the important, and, as yet, incompletely tested hypothesis, suggested above, that shallow water Hamilton biofacies persisted contemporaneously with Tully Fauna biofacies in deeper water. Thus, this dramatic "recovery" of diverse Hamilton biofacies, may merely record the recurrence of sufficiently shallow water facies to permit tracking of the high diversity shallow assemblages back into the area of the Appalachian Basin. The recurrence of shallow water elements of the Hamilton Fauna in the upper Tully, is also conceptually important to the partly tested model of Coordinated Stasis (Brett \& Baird 1995) as it suggests that certain faunal associations may remain partially intact even in the face of significant environmental change. Despite this resistance to extinction, eventually most pre-Taghanic taxa, including both neritic and pelagic forms, went extinct by the end of Taghanic time (Aboussalam \& Becker 2001, Aboussalam et al. 2001). This final extinction phase is obscured in much of our field area by the spread of anoxia associated with the Taghanic transgression. However, examination of post-Tully, nearshore neritic facies, coeval to the Geneseo Formation, presents an opportunity to reconstruct this last potential bioevent (see below).

\section{Nearshore Taghanic succession}

The Gilboa Sandstone represents nearshore marine deposits that have traditionally been considered to be coeval to the Tully Formation and to represent facies transitional between marine and nonmarine Taghanic deposits (Johnson \& Friedman 1969, Rickard 1975). In actuality, the Gilboa is poorly understood chronostratigraphically as its internal stratigraphy has yet to be mapped in enough detail to allow TFCCS units, recognized by the present authors, to be linked to the inferred paleoshore (Figs 2, 6). Given that the Geneseo Formation marks a major marine transgression above the Tully Limestone and TFCCS-successions, it is likely that some part of the Gilboa is an eastward correlative of the post-Taghanic Geneseo Formation and its shoreward, neritic equivalent, the Unadilla Formation, but this has yet to be confirmed. The present authors have extended tentative lithologic correlations into the western part of the Gilboa Sandstone as far east as Schenevus, New York where a major section through the Tully (Taghanic) interval has been recently studied in detail (Figs 2,6). This section, 1.0 kilometer south of Schenevus, is approximately 30 kilometers west of the Schoharie Valley where the first red bed tongues extending from the east are seen. In this latter area, Tully-equivalent Gilboa strata distinctly overlie the famous tree stump horizons seen at Gilboa, New York; these horizons occur in the easternmost marine facies tracts of the Cooperstown Member and are of pre-Taghanic age (Johnson \& Friedman 1969, Bartholomew et al. 2002, Baird et al. 2005). Both within and above the Gilboa Sandstone at the Schenevus section, fossiliferous strata overlie the West Brook and continue upward into the Unadilla Siltstone, a unit demonstrably equivalent to the Geneseo Formation at that meridian (Figs 2, 6). The nature of the biota within this succession is a focus of ongoing work.

\section{Significance of Lower Tully biofacies}

The onset of the first Lower Tully bioevent marked not only the incursion of key Tully Fauna taxa, but it also saw significant facies changes, both on the offshore platform and in the eastern detrital belt. The Tully Formation west of the Syracuse meridian is anomalous for its relatively pure, fine-grained carbonate relative to older and younger, thick detrital facies successions of the Hamilton and Genesee Groups. Moreover, this carbonate grades eastward into condensed chamositic "oolitic" deposits in east-central New York, which, in turn, expand greatly into sparsely fossiliferous detrital deposits in a narrow basin east of the Chenango Valley (Baird \& Brett 2003, Baird et al. 2003). Chamosite, though technically present in the Hamilton Group, is rare in that succession. Moreover, the micrite-chamosite-detrital transition actually occurs at several levels in the New 
County Road 41 roadcut and adjacent Creek Section, $1.0 \mathrm{~km}$ south of Schenevus, NY (Composite Section), Current interpretation

Unadilla Member (Geneseo Mbr. - equiv.?)

TST

SB

$$
\overbrace{\text { major discontinuity }}^{\text {West Brook Bed? }}
$$<smiles>CC</smiles>

shell lag bed, chamosite SSB

major discontinuity

"Laurens Member" (undivided lower medial) Tully Formation equiv. ?)

SSB

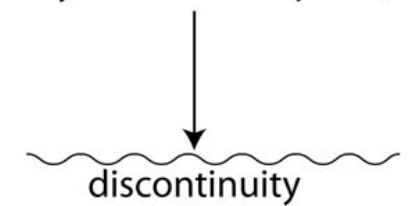<smiles>[CH][CH]</smiles>

New Lisbon

Member?

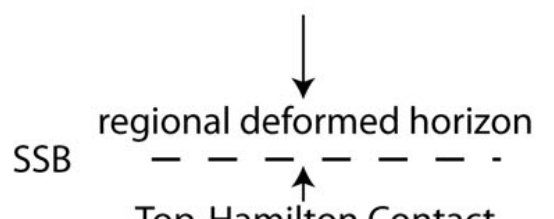

Top-Hamilton Contact

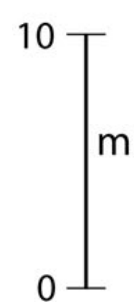

Cooperstown Member

SSB?

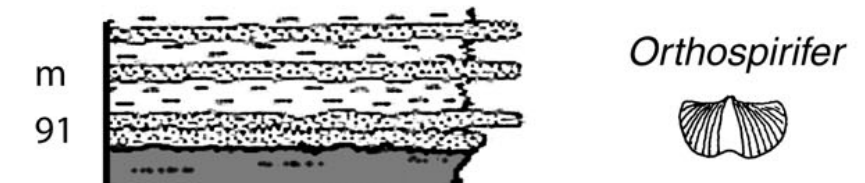

69

65.5

82

77.5
77

43

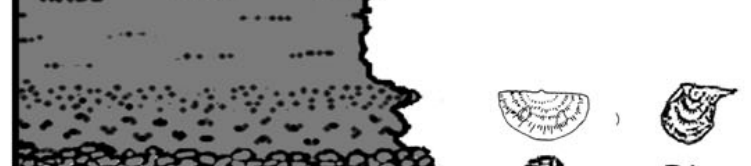

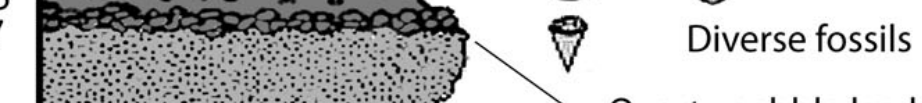

69

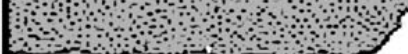

Quartz pebble lag bed

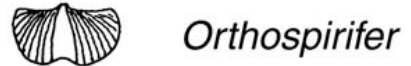

$\rightarrow \circlearrowleft$ Rhyssochonetes

Emanuella

$\begin{array}{ccc}3 & 0\end{array}$

Allanella Tropidoleptus

11

Allanella Tropidoleptus

38

37

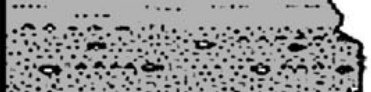

3
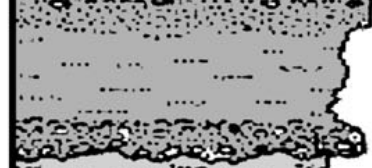

(1)

Allanella Tullypothyridina

17.5

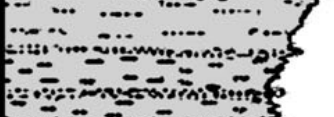

Allanella Tulypothyridina

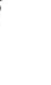


Lisbon-Tully succession indicating that it is a characteristic facies motif that is linked to the biotic changes.

Originally, the present authors concurred with Heckel (1973) that the lower Tully and coeval TFCCS represented shallow water, restricted settings comparable to lagoon and inner platform environments; the massive micrite beds, oolitic chamosite, alleged mudcracks, and microbiolitic stromatolites reported by him, were collectively suggestive of restricted platform facies (see Heckel 1973). Recent observations, however, suggest that Tully and TFCCS deposits record a spectrum of outer shelf and even dysoxic basin settings based on contextual faunal and sedimentological evidence (Baird \& Brett 2003, Baird et al. 2003). In particular, thick TFCCS detrital wedge deposits east of the Chenango Valley are sparsely fossiliferous successions of flaggy siltstone beds characterized by auloporid corals, diminutive or thin-shelled brachiopods (Emanuella, Rhyssochonetes, C. mesocostale), and styliolines. This biofacies corresponds closely to the dysoxic Eumetabolotoechia biofacies of the Hamilton Group and the "Cladochonus facies" identified as a prodelta slope signature in the overlying Genesee Group (Thayer 1974). Moreover, near-barren TFCCS facies in the basin axis near New Berlin grades eastward (upslope) into fossiliferous neritic deposits as the nearshore Gilboa Sandstone is approached (Baird \& Brett 2003). Notably, the Smyrna Bed and other similar intensely bioturbated, "oolitic" chamosite layers also yield low diversity, recurrent associations of auloporids, Emanuella, rare Tullypothyridina, and corroded pelmatozoan debris. Other lower Tully micritic facies, particularly, the Carpenter Falls Bed, lack many robust neritic components (large brachiopods, large rugose or tabulate corals, ramose and fenestrate bryozoans, and bivalves) typical of many shallow water horizons in the underlying Moscow Formation.

Given that microbialite stromatolites have now been found in association with chamositic "oolites" within the detrital TFCCS basin-fill successions in both east-central New York and central Pennsylvania, we believe that these features are not good proxies of lagoonal or other onshore restricted settings. Moreover, the absence of tidally-induced features, desiccation features, stromatoporoids, abundant gastropods, or dense ostracode concentrations in the lower Tully in western New York render a shallow, lagoonal facies argument for these beds to be problematic. In addition, the low energy micritic nature of the western New York lower Tully, the black-brown appearance of these limestones in the fresh state, and recent discovery of "Leiorhynchus" (C. mesocostale) in both the Carpenters Falls and equivalent Smyrna beds, collectively indicate a minimally oxic, outer shelf setting.

Given that the abundant small brachiopod Emanuella has also been found, both, in very shallow water and offshore Taghanic-age deposits in the Czech Republic (see
Ficner \& Havlíček 1978), one could argue that its utility as a paleoenvironmental indicator is minimal. However, given the context of ecological disruption associated with the first Taghanic bioevent, one also could see how this brachiopod, normally restricted to sub-optimal dysoxic habitats during pre-Taghanic times, could have opportunistically invaded neritic settings following ecological collapse of the Hamilton Fauna.

In summary, most lower Tully and corresponding TFCCS divisions yielding Tully Fauna taxa are moderate to low diversity biofacies suggestive of variably stressed bottom conditions (Baird \& Brett 2003, Baird et al. 2003). We propose that this reflects a complex deterioration of habitats associated with the first Taghanic bioevent that enabled certain "Old World Realm" taxa to invade the basin and allowed opportunistic forms to migrate onto the open shelf. The primal global cause(s) of this event are potentially many, but, locally, the triggering event may have been the overspread of warm, tropical waters across the region.

\section{Post-Taghanic biotic changes}

Ongoing fieldwork is directed toward the goal of extending correlational tie lines eastward across the nearshore facies belt of the Gilboa Sandstone and overlying (post-Taghanic) Unadilla Formation. Preliminary examination of the westernmost Gilboa Sandstone near Schenevus (Figs 2, 6) shows that, at least, one key brachiopod taxon Orthospirifer mesastrialis, typical of the post-Taghanic Ithaca Fauna, becomes important within the Tully interval as well (Fig. 6). This taxon, co-occurs with Allanella and Tropidoleptus, two brachiopods absent from the Tully Fauna, but common to both the Hamilton and Ithaca faunas (Fig. 6). This information suggests that some faunal reorganization was taking place in eurytopic, nearshore settings during Taghanic time. This is not surprising given that these settings were characterized by turbidity and salinity related stresses and by low diversity biofacies generally. As with the lower diversity, offshore, dysoxic biofacies, paleocommunities would have been more loosely structured and open to incursion by opportunistic generalists. Hence, these associations should "blur" into one another temporally, owing to the nature of nearshore ecology. Finally, the abundance of Orthospirifer in nearshore facies and its essential absence from even the most diverse biofacies in the Tully Limestone, does offer the possibility that the incursion of the Ithaca Fauna had begun during deposition of the TFCCS, but had not advanced significantly to influence either the typical Tully or Hamilton faunas. This final displacement appears to taken place in strata above the visible Tully Formation, perhaps in neritic facies of the little-studied Unadilla Siltstone; examination of biofacies in this unit is a central priority noted above. Through this ongoing work, we should be able to determine the fate of the Ha- 
milton Fauna, particularly, its relationship to the Ithaca fauna, and whether it had indeed survived into the Late Givetian. Such work was initially undertaken by H.S. Williams (1913) in a detailed and prescient study of a recurrent brachiopod association having several genera in common with some Hamilton associations. This assemblage occurs in Frasnian strata far above the Tully interval. This association has yet to be re-examined by the present authors, but it suggests that the Hamilton Fauna may, in part, have survived in refugia and repeatedly propagated from these refugia.

\section{Acknowledgments}

We thank Tim Philips for help with figure preparation; field work in New York was partially supported by grants from the USGS STATEMAP program and by NSF-9725441. We also thank Alex Bartholomew for assistance with fieldwork and Ralph Thomas Becker for critical reviews of this paper.

\section{References}

ABOussalaM, Z.S. 2003. Das "Taghanic-event" im höheren Mittel-Devon von West-Europa und Marokko. Münsterische Forschungen zur Geologie und Paläontologie 97, 1-330.

ABOUSSALAM, Z.S. \& BECKER, R.T. 2001. Prospects for an Upper Givetian Substage. Mitteilung Museum Naturkunst Berlin Geowissenschaft Reihe 4, 83-99.

ABOUSSALAM, Z.S., BECKER, R.T. \& SCHULTZ, H.-P. 2001. The global Taghanic biocrisis in the Upper Givetian (Middle Devonian). $15^{\text {th }}$ Annual Senckenberg Conference; Mid-Palaeozoic Bio- and Geodynamics, The North Gondwana-Laurussia Interactions; Abstracts 1. Frankfurt am Main.

BAIRD, G.C. \& BRETT, C.E. 1986. Erosion on an anaerobic seafloor: significance of reworked pyrite deposits from the Devonian of New York State. Palaeogeography, Palaeoclimatology, Palaeoecology 57, 157-193. DOI 10.1016/00310182(86)90012-X

BAIRD, G.C. \& BRETT, C.E. 1991. Submarine erosion on the anoxic seafloor, paleoenvironmental and temporal significance of reworked pyrite-bone deposits, 223-257. In TYSON, R.V. \& PEARSON, T.H. (eds) Modern and Ancient Continental Shelf Anoxia. Geological Society Special Publication 58.

BAIRD, G.C. \& BRETT, C.E. 2003. Shelf and off-shelf deposits of the Tully Formation in New York and Pennsylvania: Faunal incursions, eustasy and tectonics. Courier Forschungsinstitut Senckenberg 242, 141-156.

BAIRD, G.C., BRETT, C.E. \& BARTHOLOMEW, A.J. 2003. Late Middle Devonian biotic and sedimentologic events in east-central New York - Tully Formation clastic correlative succession in the Sherburne - Oneonta area, 1-54. In JOHnSON, E.L. (ed.) Field Trip Guidebook - New York State Geological Association, $75^{\text {th }}$ Annual Meeting.

BAIRD, G.C., BRETT, C.E. \& BARTHOLOMEW, A.J. 2005. Hybrid eustatic and flexural effects within a synorogenic clastic wedge: establishing temporal links between the Late Middle Devonian Tully Formation and the nearshore Gilboa Sandstone in eastern New York. Geological Society of America, Abstracts with Programs 37(7), 112.

Bartholomew, A.J., Brett, C.E. \& Baird, G.C. 2002. Sequence stratigraphy of Middle Devonian (Givetian) nearshore/paralic facies, eastern New York State: Stratigraphic context of the world's oldest fossilized forest. First International Paleontological Congress, Sydney, 16.

BECKER, R.T. 2005. Correlation of the proposed Middle Devonian Substage with the global ammonoid record. Document of the International Subcommission on Devonian Stratigraphy, Annual Meeting, Novosibirsk, 6 pp.

BECKER, R.T. 2007. Correlation of the proposed Middle Givetian Substage with the global ammonoid record. Subcommission on Devonian Stratigraphy, Newsletter 22, 17-23.

BRETT, C.E. \& BAIRD, G.C. 1994. Depositional sequences, cycles, and foreland basin dynamics in the late Middle Devonian (Givetian) of the Genesee Valley and western Finger Lakes region, 505-586. In BRETT, C.E. \& SCATTERDAY, J. (eds) Field Trip Guidebook - New York State Geological Association, $66^{\text {th }}$ Annual Meeting.

BRETT, C.E. \& BAIRD, G.C. 1995. Coordinated stasis and evolutionary ecology of Silurian to Middle Devonian marine biotas of the Appalachian Basin, 285-315. In ERWIN, D. \& ANSTEY, R. (eds) New Approaches to Speciation in the fossil record. Columbia University Press, New York.

Bultynck, P., COEN, A.M. \& Godefrois, J. 2000. Summary of the state of correlation in the Devonian of the Ardennes (Belgium-NE France) resulting from the decisions of the SDS, 91-114. In BULTYNCK, P. (ed.) Recognition of Devonian Series and Stage Boundaries in Geological Areas. Courier Forschungsinstitut Senckenberg 225.

BULTYNCK, P. \& WALLISER, O.H. 2000. Devonian boundaries in the Devonian Anti Atlas, 211-226. In BULTYNCK, P. (ed.) Recognition of Devonian Series and Stage Boundaries in Geological Areas. Courier Forschungsinstitut Senckenberg 225.

Chlupáč, I., Galle, A., Hladil, J. \& Kalvoda, J. 2000. Series and stage boundaries in the Devonian of the Czech Republic, 159-172. In BULTYNCK, P. (ed.) Recognition of Devonian Series and Stage Boundaries in Geological Areas. Courier Forschungsinstitut Senckenberg 225.

COOPER, G.A. \& WILliAMS, H.S. 1935. Tully Formation of New York. Geological Society of America Bulletin 46, 781-868.

Crick, R.E., Ellwood, B.B., Feist, R., El Hassani, A., SCHINDLER, E., DREESEN, R., OVER, D.J. \& GIRARD, C. 2002. Magnetostratigraphy susceptibility of the Frasnian/Famennian boundary. Palaeogeography, Palaeoclimatology, Palaeoecology 181, 67-90.

DOI 10.1016/S0031-0182(01)00473-4

EllwoOd, B.B., CRICK, R.E. \& El Hassani, A. 1997. The magnetosusceptibility event and cyclostratigraphy (MSEC) method used in geological correlation of Devonian rocks from Anti-Atlas, Morocco. American Association of Petroleum Geologists Bulletin 83, 1119-1134. 
EllwoOd, B.B., CRICK, R.E., El HASSANI, A., BENOIST, S.L. \& YOUNG, R.H. 2000. Magnetosusceptibility event and cyclostratigraphy method applied to marine rocks: detrital input versus carbonate productivity. Geology 28(12), 1135-1138. DOI 10.1130/0091-7613(2000)28<1135:MEACMA >2.0.CO;2 EllwoOd, B.B., Garcia-Alcalde, J.L., El Hassani, A., HLAdIL, J., SOTO, F.M., TRUYOLS-MASSONI, M., WEDDIGE, K. \& KoptíKOVÁ, L. 2006. Stratigraphy of Middle Devonian Boundary: Formal definition of susceptibility magnetostratigraphy stratotype in the Czech Republic. Tectonophysics 418, 31-49. DOI 10.1016/j.tecto.2005.12.012

ETTENSOHN, F.R. 1998. Compressional tectonic controls on epicontinental black shale deposition: Devonian-Mississippian examples from North America, 109-128. In SCHIEBER, J., ZiMmerLe, W. \& SETHI, P.S. (eds) Shales and Mudstones. Volume 1: Basin Studies, Sedimentology, and Paleontology. E. Schweizerbart'sche Verlagsbuchhandlung (Nägele und Obermiller), Stuttgart.

FICNER, F. \& HAVLÍČEK, V. 1978. Middle Devonian brachiopods from Celechovice, Moravia. Sborník geologických věd, Paleontologie 21, 49-106.

GrabaU, A.W. 1917. Stratigraphic relationships of the Tully Limestone and the Genesee Shale in eastern North America. Geological Society of America Bulletin 28, 945-958.

HECKEL, P.H. 1966. Stratigraphy, petrology, and depositional environment of the Tully Limestone (Devonian) in New York State and adjacent region. $448 \mathrm{pp}$. $\mathrm{PhD}$ thesis, Rice University, Houston, U.S.A.

HECKEL, P.H. 1973. Nature, Origin, and significance of the Tully Limestone. Geological Society of America, Special Paper $139,1-244$.

HLADIL, J. 1994. Moravian Middle and Late Devonian buildups: evolution in time and space with respect to Laurussian shelf. Courier Forschungsinstitut Senckenberg 172, 111-125.

Hladil, J., GerŠL, M., Strnad, M., FrÁnA, J., LANGROVÁ, A. \& SPIŠIAK, J. 2006. Stratigraphic variation of complex impurities in platform limestones and possible significance atmospheric dust: a study with emphasis on Gamma-ray spectrometry and magnetic susceptibility outcrop logging (Eifelian-Frasnian, Moravia, Czech Republic). International Journal of Earth Sciences (Geologische Rundschau) 95(4), 703-723. DOI 10.1007/s00531-005-0052-8

HouSE, M.R. 1962. Observations on the ammonoid succession of the North American Devonian. Journal of Paleontology 36, 247-284.

HousE, M.R. 1978. Devonian ammonoids from the Appalachians and their bearing on international zonation and correlation. Special Papers in Palaeontology 21, 1-70.

HousE, M.R. 1981. Lower and Middle Devonian goniatite biostratigraphy, 3-37. In OLIVER, W.A. JR. \& KLAPPER, G. (eds) Devonian Biostratigraphy of New York, Part 1 Text-International Union of Geological Sciences, Subcommission on Devonian Stratigraphy.
House, M.R. 2002. Strength, timing, cause and effect of MidPaleozoic extinctions. Palaeogeography, Palaeoclimatology, Palaeoecology 181, 5-75. DOI 10.1016/S0031-0182(01)00471-0

HuDDLE, J. 1981. Conodonts from the Genesee Formation in western New York. United States Geological Survey, Professional Paper 1032B, 1-66.

JOHNSON, J.G. 1970. The Taghanic onlap and the end of North American Devonian provinciality. Geological Society of America Bulletin 81, 2077-2106.

Johnson, J.G., KlAPPER, G. \& SANDBERG, C.A. 1985. Devonian eustatic fluctuations in Euramerica. Geological Society of America Bulletin 96, 567-587.

JOHnSON, K.G. \& FRIEDMAN, G.M. 1969. The Tully clastic correlative succession (Upper Devonian) of New York State: a model for recognition of alluvial, dune (?), tidal, nearshore (bar and lagoon), and offshore sedimentary environments in a tectonic delta complex. Journal of Sedimentary Petrology 39(2), 451-485.

KIRCHGASSER, W.T. 2000. Correlation of stage boundaries in the Appalachian Devonian, eastern United States, 271-284. In Bultynck, P. (ed.) Recognition of Devonian Series and Stage Boundaries in Geological Areas. Courier Forschungsinstitut Senckenberg 225.

KLAPPER, G. 1981. Review of New York State conodont biostratigraphy, 57-66. In OLIVER, W.A. JR. \& KLAPPER, G. (eds) Devonian Biostratigraphy of New York, Part 1 Text - International Union of Geological Sciences, Subcommission on Devonian Stratigraphy.

RICKARD, L.V. 1975. Correlation of the Silurian and Devonian rocks of New York State. New York State Museum and Science Service, Map and Chart Series 24, 16 pp., 4 charts.

SARTENAER, P. 2003. Tullypothyridina, a new late Givetian rhynchonellid (brachiopod) genus. Bulletin de l'Institut Royal des Sciences Naturelles de Belgique, Sciences de la Terre 73, $29-51$.

Sessa, J., BretT, C.E., Miller, A.I. \& BAIRD, G.C. 2002. The dynamics of rapid, asynchronous biotic turnover in the Middle Devonian Appalachian Basin of New York. Geological Society of America, Abstracts with Programs 34(2), A117.

THAYER, C.W. 1974. Marine paleoecology in the Upper Devonian of New York. Lethaia 7, 121-155.

TRAINER, D.W., JR. 1932. The Tully Limestone of central New York. Bulletin, New York State Museum 291, 1-43.

WILLARD, B. 1937. Tully Limestone and faunas in Pennsylvania. Geological Society of America Bulletin 48, 1237-1256.

WILLIAMS, H.S. 1913. Recurrent Tropidoleptus faunas of the Upper Devonian in New York. United States Geological Survey, Professional Paper 79, 1-103.

ZIEGLER, W., KLAPPER, G. \& JOHNSON, J.G. 1976. Redefinition and subdivision of the varcus-zone (Conodonts, Middle-?Upper Devonian) in Europe and North America. Geologie et Palaeontologie 10, 109-140. 